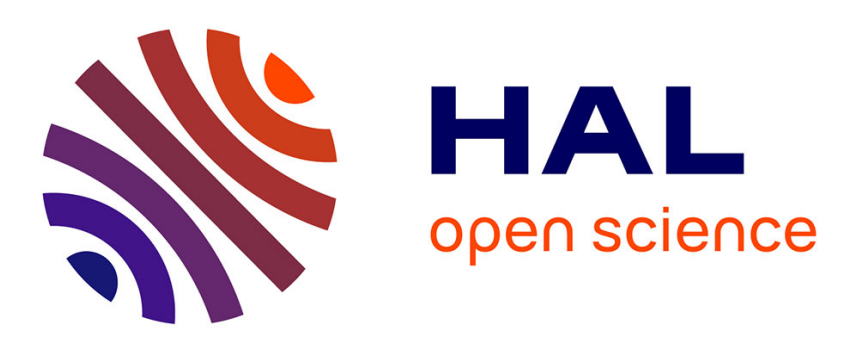

\title{
Chiral electron-rich bis(cyclopentadienyl) dithiolene molybdenum complexes
}

Yann Le Gal, Thierry Roisnel, Vincent Dorcet, Thierry Guizouarn, Lidia Piekara Sady, Dominique Lorcy

\section{- To cite this version:}

Yann Le Gal, Thierry Roisnel, Vincent Dorcet, Thierry Guizouarn, Lidia Piekara Sady, et al.. Chiral electron-rich bis(cyclopentadienyl) dithiolene molybdenum complexes. Journal of Organometallic Chemistry, 2015, 794, pp.323-329. 10.1016/j.jorganchem.2015.07.021 . hal-01188190

HAL Id: hal-01188190

https://hal-univ-rennes1.archives-ouvertes.fr/hal-01188190

Submitted on 27 Oct 2015

HAL is a multi-disciplinary open access archive for the deposit and dissemination of scientific research documents, whether they are published or not. The documents may come from teaching and research institutions in France or abroad, or from public or private research centers.
L'archive ouverte pluridisciplinaire HAL, est destinée au dépôt et à la diffusion de documents scientifiques de niveau recherche, publiés ou non, émanant des établissements d'enseignement et de recherche français ou étrangers, des laboratoires publics ou privés. 


\title{
Chiral electron-rich bis(cyclopentadienyl) dithiolene molybdenum complexes
}

\author{
Yann Le Gal ${ }^{\dagger}$ Thierry Roisnel, ${ }^{\dagger}$ Vincent Dorcet, ${ }^{\dagger}$ Thierry Guizouarn, ${ }^{\dagger}$ Lidia Piekara \\ Sady, .and Dominique Lorcy ${ }^{\dagger *}$ \\ Institut des Sciences Chimiques de Rennes, UMR 6226 CNRS-Université de Rennes 1, \\ Campus de Beaulieu, Bât 10A, 35042 Rennes cedex, France.E-mail : dominique.lorcy@univ- \\ rennes1.fr \\ ${ }^{*}$ Institute of Molecular Physics, Polish Academy of Sciences, Smoluchowskiego 17, 60-179 \\ Poznan, Poland
}

\begin{abstract}
Enantiomerically pure electron rich $\mathrm{Cp}_{2} \mathrm{Mo}$ (dithiolene) complexes have been synthesized from the enantiopure dithiolene ligands, namely the $(R)$ - and the $(S)-3(1-$ phenylethyl)-1,3-thiazoline-2-thione-4,5-dithiolate ligands. These heteroleptic molybdenum complexes act as very good electron donors, as demonstrated through electrochemical investigations. Both isomers form charge transfer salts with TCNQ with a 1:1 stoechiometry which have been characterized by single crystal X-ray diffraction, EPR and UV-vis spectroscopic investigations. Circular dichroism (CD) experiments were also carried out on the neutral $(R)$ and $(S)$ enantiomers as well as on the mono oxidized species of these $\mathrm{Cp}_{2} \mathrm{Mo}$ dithiolene complexes.
\end{abstract}

Keywords: Molybdocene, Dithiolene, Chirality, Thiazole, charge transfer salt

\section{Introduction}

Molybdenum dithiolene complexes, beside their interest as model compounds for understanding the role of molybdenum enzymes, ${ }^{1}$ belong to an electron rich class of donor 
molecules which can act as precursors for the formation of various charge transfer complexes. ${ }^{2}$ More specifically, bis(cyclopentadienyl) molybdenum dithiolene complexes, namely $(\mathrm{Cp})_{2} \mathrm{Mo}$ (dithiolene), where the dithiolene ligand is differently substituted, have focused the interest in this frame. These $\mathrm{d}^{2}(\mathrm{Cp})_{2} \mathrm{Mo}$ (dithiolene) complexes can be reversibly oxidized to the formally $\mathrm{d}^{1}$ radical cation and then to the formally $\mathrm{d}^{0}$ dicationic species at redox potentials which can vary with the donating electron ability of the dithiolene ligand. Associated with the oxidation state of the complex and the electron donating ability of the

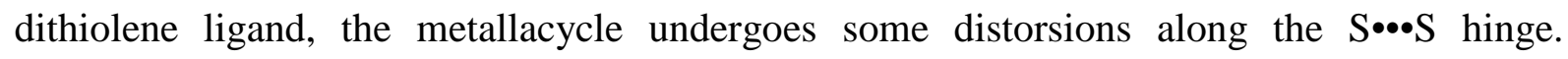
Actually going from the formal $\mathrm{d}^{2}$ to $\mathrm{d}^{1}$ and $\mathrm{d}^{0}(\mathrm{Cp})_{2} \mathrm{Mo}$ (dithiolene) complexes the folding

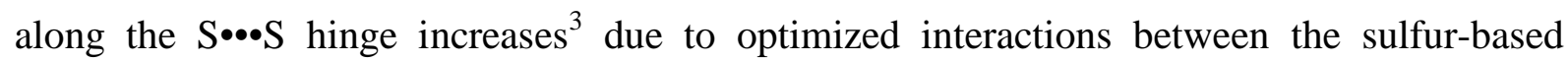
orbitals and the metal $\mathrm{d}$ orbital. ${ }^{4}$ As the generation of the cation radical species of these complexes can be easily reached, either chemically or electrochemically, various magnetic molecular materials have been obtained. ${ }^{5,6}$ The ease to reach the cation radical state depends on the electron rich character of the dithiolene ligand. ${ }^{7}$ Our current interest on the synthesis of either homoleptic ${ }^{8,9}$ or heteroleptic ${ }^{10,11}$ metal dithiolene complexes involving the electron rich $\mathrm{N}$-alkyl-1,3-thiazoline-2-thione-4,5-dithiolate (R-thiazdt) ligand prompted us to investigate the corresponding $\mathrm{Cp}_{2} \mathrm{Mo}$ (dithiolene) complexes, and more specifically chiral ones. Indeed, thanks to the nitrogen substituent of the thiazole core it is possible to insert a chiral substituent and to use this precursor in the preparation of chiral ligand. ${ }^{12}$ On this basis, we investigated the synthesis of $\mathrm{Cp}_{2} \mathrm{Mo}$ (dithiolene) complexes of general formulae $\mathrm{Cp}_{2} \mathrm{Mo}(\mathrm{R}$ *-thiazdt), (Chart 1). Herein, the synthesis of the enantiopur complexes as well as the racemic mixture will be described together with their ability to form charge transfer salts with TCNQ. The X-ray crystal structures, magnetic properties as well as the chiroptical properties will be presented. 


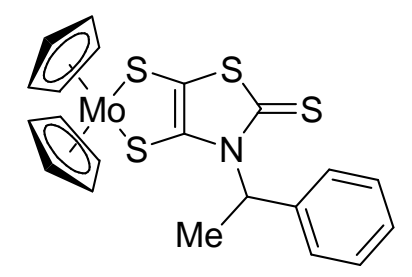

$\mathrm{Cp}_{2} \operatorname{Mo}\left(\mathbf{R}^{*}\right.$-thiazdt $)$

\section{Results and Discussion}

\section{Synthesis and characterization.}

The dithiolene complexes were prepared from the enantiopur or the racemic mixture of $\mathrm{N}-1$ phenylethyl-4,5-bis(cyanoethylthio)-1,3-thiazoline-2-thione $(R)$-, $(S)$ - and $(R, S)$-1 (Scheme 1). This compound $\mathbf{1}$ is a protected form of the dithiolate ligand, where the two thiolates are protected by cyanoethyl groups. ${ }^{12}$<smiles>CCCCCC(C)n1c(SCCC#N)c(SCCC#N)sc1=S</smiles>

$(R)-1$

$(S)-1$ $(R / S)-1$ $\underset{\text { i) } \mathrm{NaOMe}}{\stackrel{\mathrm{Cp}}{\mathrm{Cp}} \mathrm{MoCl}_{2}}$

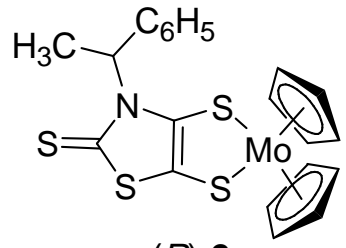

$(R)-2$

(S)-2

$(R / S)-2$

Scheme 1. Synthesis of the $(R)-,(S)$ - and $(R, S)-\mathrm{Cp}_{2} \mathrm{Mo}$ (dithiolene) complexes 2.

Deprotection of the dithiolate ligand was performed in basic medium using $\mathrm{NaOMe}$, and addition of $\mathrm{Cp}_{2} \mathrm{MoCl}_{2}$ afforded the dithiolene complexes $(R)-,(S)$ - and $(R, S)-\mathbf{2}$ as air stable, dark red crystalline materials. Interestingly, the ${ }^{1} \mathrm{H}$ NMR spectra of $(R)-,(S)-$ and $(R, S)-2$ show two broad signals for the cyclopentadienyl groups at 5.21 and $5.47 \mathrm{ppm}$ indicating that there are not equivalent. This nonequivalence of the $\mathrm{Cp}$ rings is unusual for $\mathrm{Cp}_{2} \mathrm{Mo}$ (dithiolene complexes. For instance, for other $\mathrm{Cp}_{2} \mathrm{Mo}(\mathrm{R}$-thiazdt) complexes with the same thiazole-2thione dithiolate backbone, but with smaller substituents on the nitrogen atom of the thiazole 
ring, $\left(\mathrm{R}=\mathrm{Me}\right.$, Et, and $\left.\mathrm{CH}_{2} \mathrm{CH}_{2} \mathrm{OH}\right)$, only one signal for the two $\mathrm{Cp}$ rings $(10 \mathrm{H})$ was observed at 5.52-5.58 ppm. ${ }^{11}$ The presence of the bulkier N-phenylethyl substituent generates different surroundings for the $\mathrm{Cp}$ rings and one $\mathrm{Cp}$ ring could be subject to the magnetic anisotropy effect of the phenyl ring inducing a shielding effet of one $\mathrm{Cp}$ ring placed close to the plane of the benzene ring. On the ${ }^{1} \mathrm{H}$ NMR spectra, the signal for the $\mathrm{C}-\mathrm{H}$ at $6.87 \mathrm{ppm}$ is also strongly broadened. This is reminiscent of what was observed for $\mathbf{1}^{12}$ and other N(-1-phenylethyl)thiazoline-2-thione derivatives where broad signals were attributed to the presence of two rotamers, syn and anti, depending on the orientation of the smallest substituent $(\mathrm{C}-\mathrm{H})$ in the plane of the thiazole rings (Scheme 2). ${ }^{13}$ Accordingly, a temperature-dependent ${ }^{1} \mathrm{H}$ NMR study in $\left(\mathrm{CD}_{3}\right)_{2} \mathrm{CO}$ was carried out on $(R)-2$ from ambient temperature to $198 \mathrm{~K}$. Upon lowering the temperature, the two broad signals attributed to the non-equivalent $\mathrm{Cp}$ rings become two sharp singlets while the broad signal at $6.87 \mathrm{ppm}$ for the $\mathrm{C}-\mathrm{H}$ becomes a sharp quadruplet at $258 \mathrm{~K}$. Therefore, as already noticed in the study carried out on $(R)-\mathbf{1}$, the $\mathrm{Cp}_{2} \mathrm{Mo}\left(\mathrm{R}\right.$-thiazdt) $(R)-2$ exists predominantly in one rotamer form. ${ }^{12}$

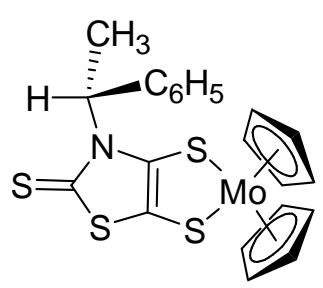

$(R)-2$ anti

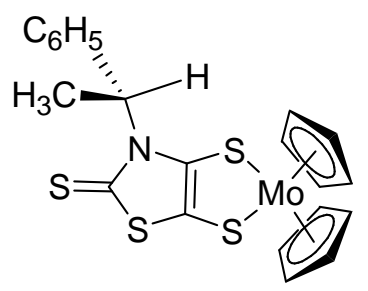

(R)-2 syn

Scheme 2. Representation of the two rotamers, anti and syn, of the complex $(R)-\mathbf{2}$.

Cyclic voltammetric studies were carried out in $\mathrm{CH}_{2} \mathrm{Cl}_{2}$ using $\mathrm{Bu}_{4} \mathrm{NPF}_{6}$ as supporting electrolyte. The complexes $(R)-\mathbf{2},(S)-2$ and $(R, S)$-2 exhibit on the cyclic voltammograms (CV) two reversible oxidation waves associated with the oxidation of the neutral derivative to the cation radical and to the dication species typical for this type of $\mathrm{d}^{2}$ molybdenum 
complexes. Compared with the $\mathrm{Cp}_{2} \mathrm{Mo}$ (Et-thiazdt), no significant difference of the redox potentials is observed (Table 1).

\section{Table 1}

Redox potentials of $\mathrm{Cp}_{2} \mathrm{Mo}\left(\mathrm{R}\right.$-thiazdt), $\Delta \mathrm{E}=E_{1 / 2}^{1}-E_{1 / 2}^{2}$

\begin{tabular}{llll}
\hline & $E_{1 / 2}^{1}$ & $E_{1 / 2}^{2}$ & $\Delta \mathrm{E}$ en mV \\
\hline $\mathrm{Cp}_{2} \mathrm{Mo}\left(\mathrm{C}^{*} \mathrm{R}\right.$-thiazdt) $(R)-2$ & 0.18 & 0.83 & 650 \\
$\mathrm{Cp}{ }_{2} \mathrm{Mo}\left(\mathrm{C}^{*} \mathrm{~S}\right.$-thiazdt) $(S)-\mathbf{2}$ & 0.16 & 0.82 & 660 \\
$\mathrm{Cp}_{2} \mathrm{Mo}($ Et-thiazdt $)$ & 0.19 & 0.81 & 620 \\
$\mathrm{Cp}_{2} \mathrm{Mo}($ dmit $)$ & 0.39 & 1.03 & 640 \\
\hline
\end{tabular}

\section{Crystal structure determinations}

Single crystals of good-quality for X-ray diffraction studies were obtained by slow evaporation of an acetone solution for $(R, S)-2$ and $(R)-2$ and by slow evaporation of a THF solution for $(S)$-2. Figure 2 shows the molecular structures for $(S)-2$ and $(R)-2$ resolved in the monoclinic space group $\mathrm{P} 2{ }_{1}$, with one molecule in general position, while the racemic mixture, $(R, S)-\mathbf{2}$ crystallizes in the triclinic space group $\mathrm{P} 1$, with four crystallographically independent molecules. Geometrical characteristics of $(R)-\mathbf{2},(S)-\mathbf{2}$ and $(R, S)-\mathbf{2}$ are collected in Table 2 together with those of the achiral $\mathrm{Cp}_{2} \mathrm{Mo}($ Et-thiazdt $)$ analog. ${ }^{11}$
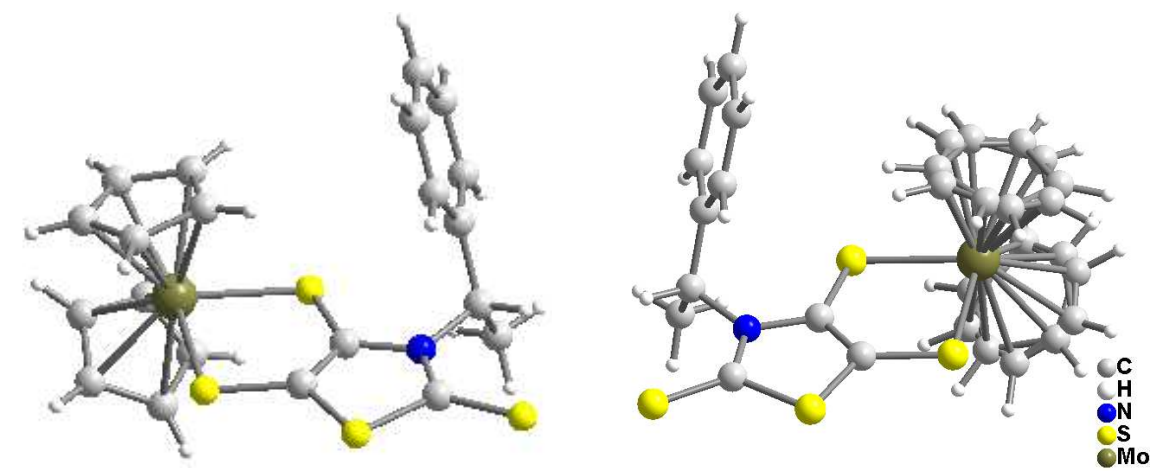

Fig. 1. Molecular structures of $(S)-2$ (left) and (R)-2 (right). 
As previously observed for similar heteroleptic complexes, such as $\mathrm{Cp}_{2} \mathrm{Mo}(\mathrm{dmit})^{6 \mathrm{~d}}$ and $\mathrm{Cp}_{2} \mathrm{Mo}$ (R-thiazdt) ${ }^{11}$ with $\mathrm{R}=\mathrm{Me}$, Et, $\mathrm{CH}_{2} \mathrm{CH}_{2} \mathrm{OH}$, these complexes exhibit the same structural trends : the thiazole cores are planar, the metallacycles weakly folded along the $\mathrm{S} \bullet \bullet \mathrm{S}$ axis with an angle lying in the range $2.9-13.2^{\circ}$ and due to the asymmetrical character of the dithiolene ligand, two different Mo-S and S-C bond lengths within the metallacycle are observed contrary to what is observed for the $\mathrm{Cp}_{2} \mathrm{Mo}$ (dmit) complex (Table 2). Another feature is the disposition of the substituent on the nitrogen as, in all the structures $(S)-\mathbf{2},(R)-\mathbf{2}$ and $(R, S)-2$, the rotamer anti is obtained (Figure 1 and Scheme 2). Within this conformation, the phenyl ring, close to one $\mathrm{Cp}$ ring, causes an upfield shift of the signal attributed to this $\mathrm{Cp}$ ring while the second $\mathrm{Cp}$ ring does not undergo this effect. As a consequence two signals are observed for the two $\mathrm{Cp}$ rings.

\section{Table 2}

Significant bond lengths $(\AA)$ and angles $\left(^{\circ}\right)$ within the metallacycle in $(R)-\mathbf{2},(S)-\mathbf{2}$ and $(R, S)-\mathbf{2}$ and their TCNQ salts.

\begin{tabular}{clllll}
\hline Compound & \multicolumn{1}{c}{ Mo-S } & \multicolumn{1}{c}{ S-C } & C=C & S-Mo-S & $\theta$ \\
\hline$(S)-2$ & $2.463(2), 2.454(3)$ & $1.749(6), 1.750(7)$ & $1.345(10)$ & $84.80(6)$ & $9.99(21)$ \\
$(R)-2$ & $2.461(1), 2.450(2)$ & $1.741(2), 1.754(4)$ & $1.345(4)$ & $84.75(3)$ & $9.70(8)$ \\
& & & & & \\
$(R, S)-2$ & $2.459(3), 2.448(3)$ & $1.744(8), 1.746(7)$ & $1.34(1)$ & $85.04(6)$ & $0.40(17)$ \\
& $2.465(3), 2.448(4)$ & $1.753(7), 1.732(7)$ & $1.361(10)$ & $84.80(7)$ & $6.74(16)$ \\
& $2.474(2), 2.467(4)$ & $1.744(7), 1.743(8)$ & $1.351(10)$ & $83053(6)$ & $13.20(15)$ \\
& $2.455(3), 2.440(3)$ & $1.745(7), 1.724(8)$ & $1.352(10)$ & $84.96(7)$ & $2.96(20)$ \\
$\mathrm{Cp}_{2} \mathrm{Mo}(\mathrm{Et}-\mathrm{thiazdt})$ & $2.469(1) \mathrm{S}, 2.485(1)$ & $1.743(2) \mathrm{S}, 1.756(2)$ & $1.346(3)$ & $84.40(2)$ & $6.04(5)$ \\
$\mathrm{Cp}{ }_{2} \mathrm{Mo}(\mathrm{dmit})$ & $2.457(3)$ & $1.745(9)$ & $1.357(12)$ & $83.9(1)$ & $5.2(2)$ \\
{$[(R)-2][\mathrm{TCNQ}]$} & $2.478(1), 2.446(1)$ & $1.714(3), 1.709(3)$ & $1.390(4)$ & $84.02(3)$ & $8.03(7)$ \\
{$[(S)-2][\mathrm{TCNQ}]$} & $2.474(1), 2.446(1)$ & $1.710(5), 1.701(4)$ & $1.397(6)$ & $83.97(4)$ & $8.05(11)$ \\
& & & & & \\
{$\left[\mathrm{Cp}_{2} \mathrm{Mo}(\right.$ Et-thiazdt)][TCNQ] $]$} & $2.475(8), 2.456(5)$ & $1.714(4), 1.699(6)$ & $1.401(5)$ & $84.24(2)$ & $14.04(5)$ \\
\hline
\end{tabular}




\section{Charge transfer salts with TCNQ.}

According to the low oxidation potentials of complexes 2 , similar to those of $\mathrm{Cp}_{2} \mathrm{Mo}(\mathrm{Et}-$ thiazdt) which formed charge transfer salts with TCNQ, we decided to associate $(R)-\mathbf{2}$ and (S)-2 with TCNQ which is reduced at $0.18 \mathrm{~V}$ vs SCE. For that purpose, we mixed a hot solution of the Mo complex 2 in $\mathrm{CH}_{2} \mathrm{Cl}_{2}$ with a hot solution of TCNQ in $\mathrm{CH}_{3} \mathrm{CN}$. The charge transfer salts were obtained as deep violet crystals. Analysis of nitrile stretching absorption band in the FTIR spectrum allowed us to determine the degree of charge transfer between the complex 2 and the TCNQ. The nitrile vibration band observed for both salts was found at $v_{\mathrm{CN}}$ $=2190$ and $2183 \mathrm{~cm}^{-1}$ for $[(R)-2][\mathrm{TCNQ}]$ and $[(S)-2][\mathrm{TCNQ}]$ respectively which is close to the energy value reported for $\mathrm{TCNQ}^{-1}\left(\mathrm{v}_{\mathrm{CN}}=2185 \mathrm{~cm}^{-1}\right)$ in its sodium salt. ${ }^{14}$ Therefore from this analysis, a charge close to -1 is deduced for the TCNQ indicating that the complexes obtained are under the cation radical form, $\mathbf{2 a}^{\mathbf{+}^{\bullet}}$ in both case.

The salts with $(R)-\mathbf{2}$ and $(S)-\mathbf{2}$ crystallize in the orthorhombic system space group P $222_{1} 2_{1}$, and are formulated as $[(R)-2][\mathrm{TCNQ}]$ and $[(S)-2][\mathrm{TCNQ}]$, that is with a 1:1 stoichiometry. Within these salts, the $\mathrm{Cp}_{2} \mathrm{Mo}$ complex as well as the TCNQ are subject to bond lengths modifications due to the redox reaction between these two components (Table 2). For the $\mathrm{Cp}_{2} \mathrm{Mo}$ complex, compared with the neutral species, these modifications occur essentially on the metallacycle ring. Due to the oxidation which essentially affects the dithiolene moiety, the $\mathrm{C}-\mathrm{S}$ bonds are shortened while the $\mathrm{C}=\mathrm{C}$ bond is lengthened. Note that the folding angle of the metallacycle along the S•••S hinge is not much modified when compared with the neutral and oxidized complexes. As already demonstrated, this trend indicates that oxidation essentially affects the dithiolene ligand, a consequence of its electron rich character. The extend of these modifications in these two TCNQ salts is in the same range as those observed for simpler complexes $\mathrm{Cp}_{2} \mathrm{Mo}$ (R-thiazdt) with $\mathrm{R}=\mathrm{Me}$, Et, $\mathrm{CH}_{2} \mathrm{CH}_{2} \mathrm{OH}$ as exemplified in Table 2 with 
$\mathrm{Cp}_{2} \mathrm{Mo}$ (Et-thiazdt). ${ }^{11}$ Due to its reduction, the acceptor skeleton is also subject to bond lengths modifications (Table 3). Using the empirical formula of Kistenmacher, which correlates the formal charge on the TCNQ with its bond lengths we found that within both complexes, $[(R)$ 2][TCNQ] and [(S)-2][TCNQ], the TCNQ is reduced but according to this empirical formulae to a smaller degree of charge transfer than the one found by FTIR investigations (Table 3).

\section{Table 3}

Significant intramolecular averaged bond lengths $(\AA)$ in TCNQ salts. The charge $(\rho)$ in TCNQ compounds is calculated according to the Kistenmacher formula which reads as $\rho=A\left(\frac{c}{b+d}\right)+B$ with $\mathrm{A}=-41.667$ et $\mathrm{B}=19.833$.

\begin{tabular}{lcccccc}
\hline${ }_{\mathrm{NC}}^{\mathrm{NC}}$ & $\mathrm{a}(\AA)$ & $\mathrm{b}(\AA)$ & $\mathrm{c}(\AA)$ & $\mathrm{d}(\AA)$ & $\rho$ & $v_{C N}\left(\mathrm{~cm}^{-1}\right)$ \\
\hline $\mathrm{TCNQ}^{0}$ & 1.346 & 1.448 & 1.374 & 1.441 & -0.02 & 2227 \\
{$\left[\mathrm{Na}^{+}\right] \mathrm{TCN}$} & 1.354 & 1.427 & 1.419 & 1.420 & -0.94 & 2185 \\
{$\left[\mathrm{Cp}_{2} \mathrm{Mo}(\right.$ Et-thiazdt $\left.)\right][\mathrm{TCNQ}]$} & 1.3655 & 1.428 & 1.422 & 1.425 & -0.94 & 2180 \\
{$[(R)-2][\mathrm{TCNQ}]$} & 1.3535 & 1.43425 & 1.4105 & 1.423 & -0.74 & 2190 \\
{$[(S)-2][\mathrm{TCNQ}]$} & 1.347 & 1.441 & 1.398 & 1.421 & -0.52 & 2183
\end{tabular}

As shown in Figure 2, in the solid state, the TCNQ form dimers and these dimers are sandwiched by two $\mathrm{Cp}_{2}$ Mo complexes in a $\bullet \cdot \mathrm{DAAD} \bullet \bullet(\mathrm{D}=\mathbf{2}$ and $\mathrm{A}=\mathrm{TCNQ})$ motif. Within these TCNQ dimers, a rotation of the molecular long axis of $60^{\circ}$ between the neighboring molecules is observed. Short intermolecular S•••S contacts, equal to 3.591(1) $\AA$, can be observed along the $a$ axis between the sulfur atom of the metallacycle and the sulfur atom of the thiazole ring of neighboring complexes as depicted in Figure 2. Note also the presence of

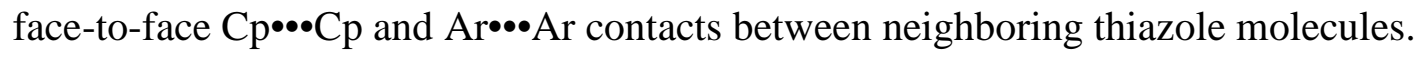



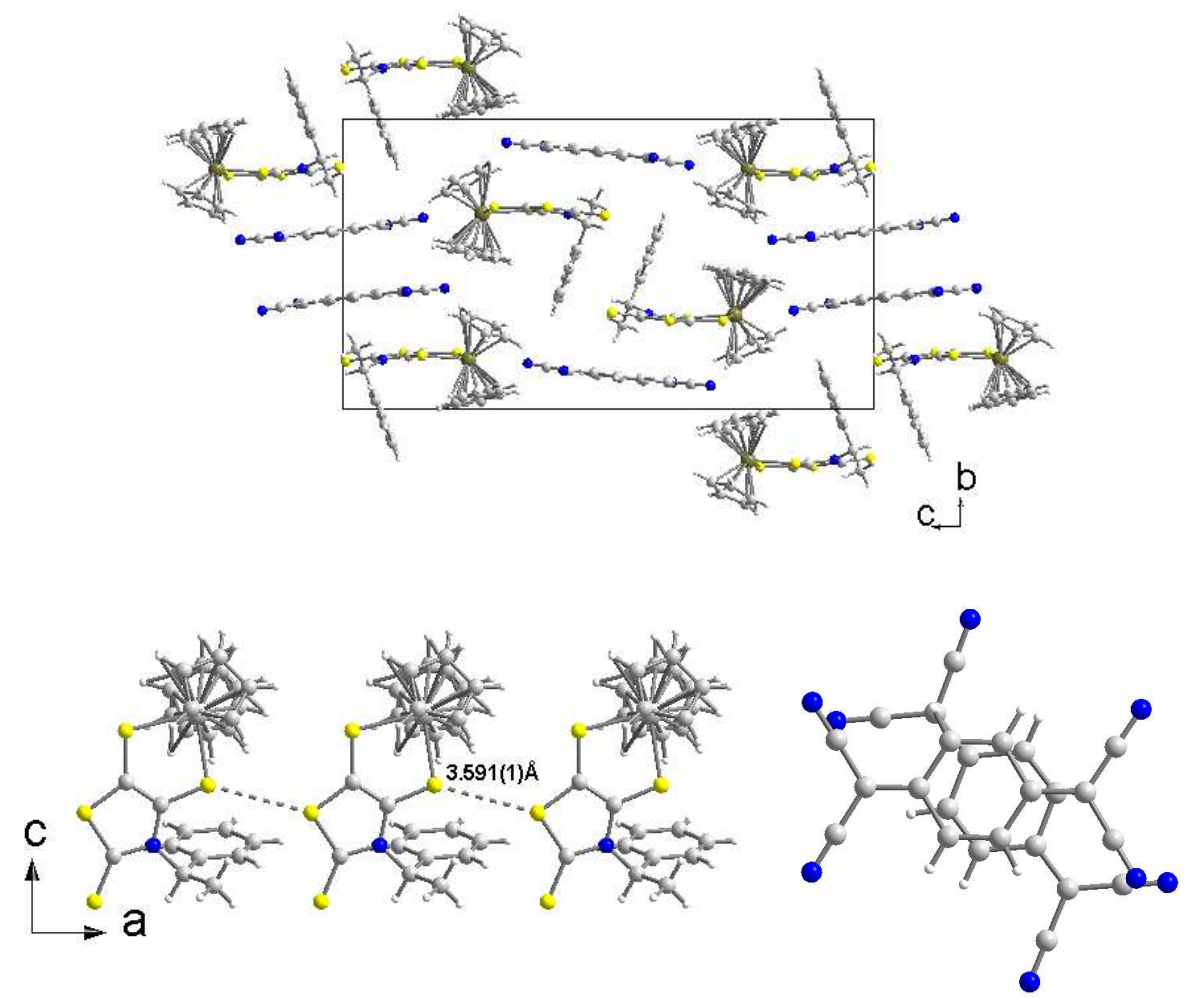

Fig. 2. View of the unit cell of $[(R)-2][T C N Q]$ along the bc plane (top) and S•••S interactions along the $a$ axis (bottom left) and TCNQ intradimer overlap (bottom right).

This structural organization strongly differs from those described previously for thiazole ring substituted by smaller substituent in $\left[\mathrm{Cp}_{2} \mathrm{Mo}(\mathrm{R}\right.$-thiazdt)][TCNQ] with $\mathrm{R}=\mathrm{Me}$, Et and $\mathrm{CH}_{2} \mathrm{CH}_{2} \mathrm{OH}$. Indeed with the smallest substituents $(\mathrm{R}=\mathrm{Me})$ the oxidized complex formed dimers due to a face-to-face overlap of the thiazole ring while for the others, lateral contacts were also observed but in a head to tail fashion. ${ }^{11}$ Herein, the steric hindrance generated by the substituent on the thiazole ring prevents the formation of overlapping dimers for the oxidized cation. Temperature dependence of the magnetic susceptibility show an essentially diamagnetic behavior with a Curie tail accounting for $7.3 \%$ and $20 \% \mathrm{~S}=1 / 2$ magnetic defaults in $[(S)-2][\mathrm{TCNQ}]$ and $[(R)-2][\mathrm{TCNQ}]$ respectively, indicating the presence of sizeable antiferromagnetic interactions within the $\left(\mathrm{TCNQ}^{\circ}\right)_{2}$ dimers as between the radical cation complexes. It was confirmed by additional EPR studies on powder samples of the two 
enantiopur and the racemic salts, by both $\mathrm{X}$ - and Q-band spectrometry. Figure 3 presents signals at $\mathrm{X}$-band at $1 \mathrm{~mW}$ and $200 \mathrm{~mW}$ for [(S)-2][TCNQ] at room temperature. Two different lines are observed which can be separated by saturation: the very narrow line ascribed to TCNQ radicals becomes indeed saturated at $200 \mathrm{~mW}$. The other almost symmetrical signal is attributed to the organometallic radical complexes $(S)-\mathbf{2}^{+\bullet}$ at $g=2.007$ with $18.5 \mathrm{G}$ linewidth. On lowering the temperature, the linewidths become continually broader.

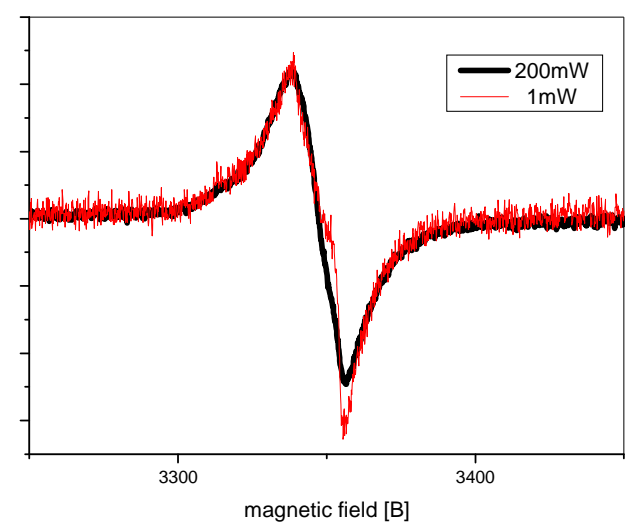

Fig.3. X-band EPR of $[(S)-2][T C N Q]$ at $1 \mathrm{~mW}$ (red) and $200 \mathrm{~mW}$ (black) microwave power. At $200 \mathrm{~mW}$ the sharp signal is saturated.

Double integration of the signals gave integral intensity proportional to spin susceptibility (Fig.4). Besides a Curie tail at lower temperatures, an additional thermally activated part is seen from a susceptibility maximum at around $175 \mathrm{~K}$. As the interactions between TCNQ radical anions are much stronger than between the $\mathbf{2}^{\mathbf{*}}$ species, this part can be attributed to the latter organometallic cations. 


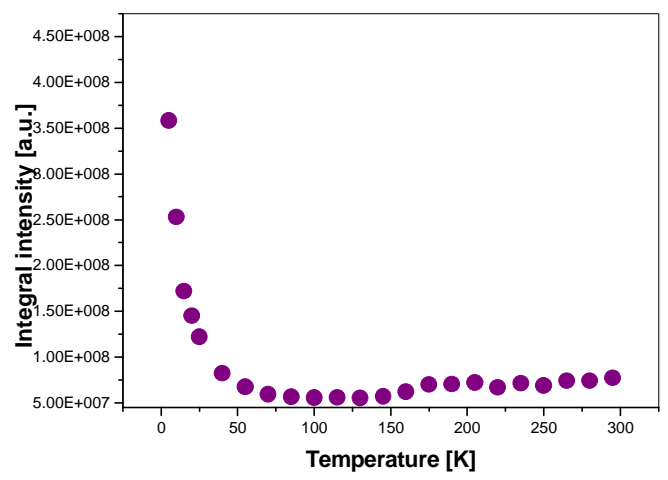

Fig.4. Integral intensity of EPR signal of [(S)-2][TCNQ] vs. temperature

The $[(R)-2][\mathrm{TCNQ}]$ and $[(R, S)-2][\mathrm{TCNQ}]$ samples also present asymmetrical signals, $[(R)-$ 2][TCNQ] having the same peak-to-peak linewidth, while the racemic mixture $[(R, S)$ 2][TCNQ] gives a much broader signal (23 G), a probable consequence of a different crystal structure. In order to get a better understanding of the spectra, Q-band EPR was also performed at room temperature. As shown in Figure 5, [(R)-2][TCNQ] exhibits an axial pattern due to the resolved $g$-anisotropy. Simulation gave $g_{/ /}=2.004$ and $g_{\perp}=2.0088$ with $g_{\text {iso }}$ $=2.007$. This is in excellent agreement with X-band EPR where a $g=2.007$ was found in $[(S)-2][T C N Q]$.

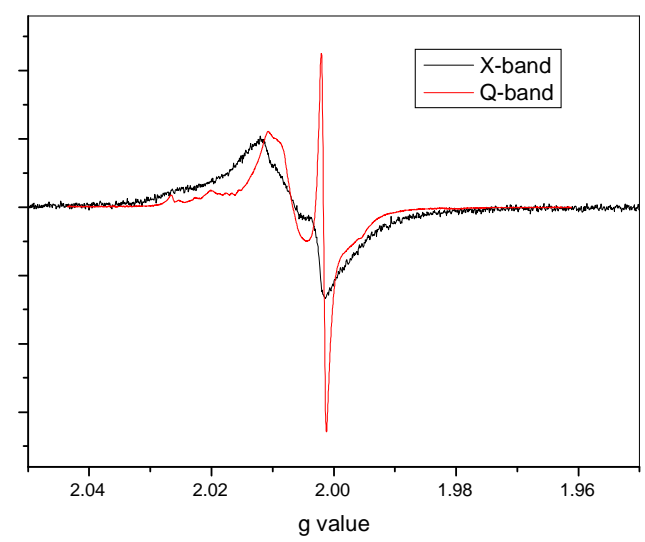

Fig. 5. X-band (black) and Q-band (red) EPR of of [(R)-2][TCNQ] at room temperature 
The UV-visible absorption spectrum of $(S)-\mathbf{2}$ is shown in Figure 3. The neutral complex exhibits absorption bands in the visible range at $\lambda_{\max }=225,259$ and $402 \mathrm{~nm}$, close to that observed for other $\mathrm{Cp}_{2}$ Modithiolene complexes. ${ }^{15,16}$ Chemical oxidation of complex $(S)$-2 was realized by a successive aliquot addition of $\mathrm{NOPF}_{6}$ and the evolution of the UV-vis spectrum is presented in Figure 6. The gradual oxidation of $(S)-2$ to the cation radical species leads to the apparition of three new bands at $\lambda_{\max }=328,472,648 \mathrm{~nm}$ together with the decrease of the band centered at $402 \mathrm{~nm}$. This evolution upon chemical oxidation is similar to the one observed through electrochemical investigation carried out on $\mathrm{Cp}_{2} \mathrm{Mo}\left(\mathrm{Et}\right.$-thiazdt). ${ }^{11}$

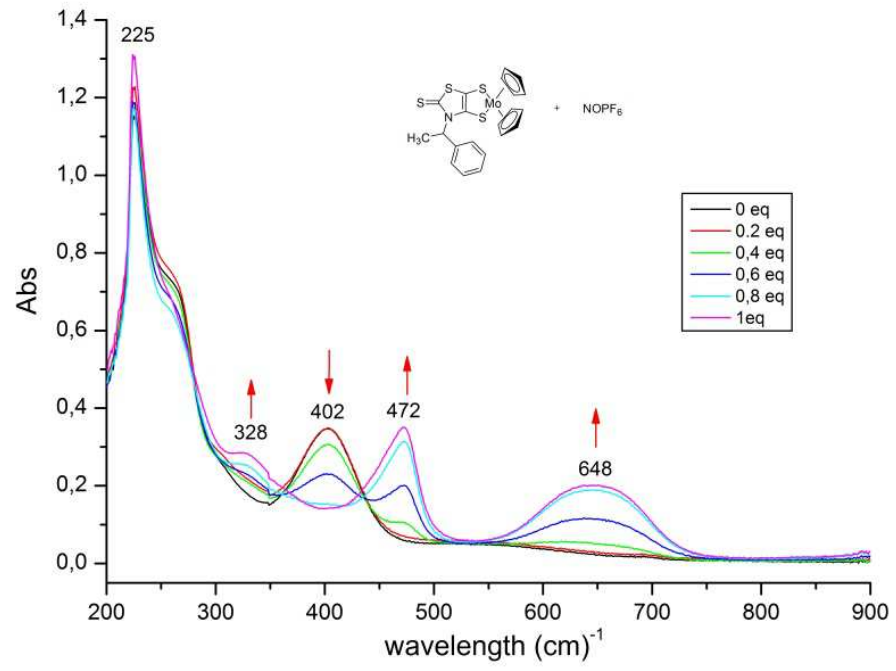

Fig. 6. Evolution of the absorption spectrum of complex $(S)-2$ in $\mathrm{CH}_{2} \mathrm{Cl}_{2}$ upon addition of increasing amounts of $\mathrm{NOPF}_{6}$ as the oxidant

The optical activity of the neutral dithiolene complexes $\mathbf{2}$ and the oxidized species in the charge transfer salt [2][TCNQ] were also investigated, in the UV-vis range. The optical activity of these complexes together with those of the organic chiral precursors $\mathbf{1}$ are reported in Table 4, as specific and molar optical rotations at two different wavelengths, (546 and 578 $\mathrm{nm})$, in the visible range. 
Table 4.

Specific and molar optical rotations of compounds $\mathbf{1}, 2$ and [2][TCNQ] in $\mathrm{CH}_{2} \mathrm{Cl}_{2}$, at $23^{\circ} \mathrm{C}$.

\begin{tabular}{lcccccc}
\hline & $(R)-\mathbf{1}$ & $(S)-\mathbf{1}$ & $(R)-\mathbf{2}$ & $(S)-\mathbf{2}$ & {$[(R)-\mathbf{2}][\mathrm{TCNQ}]$} & {$[(S)-\mathbf{2}][\mathrm{TCNQ}]$} \\
\hline$[\alpha]_{578}$ & +258 & -253 & +90 & -80 & +90 & -90 \\
{$[\alpha]_{546}$} & +312 & -305 & +210 & -220 & +120 & -110 \\
{$[\Phi]_{578}$} & 1010 & -990 & 460 & -409 & +642 & -643 \\
{$[\Phi]_{546}$} & 1221 & -1194 & 1073 & -1124 & +856 & -785 \\
\hline
\end{tabular}
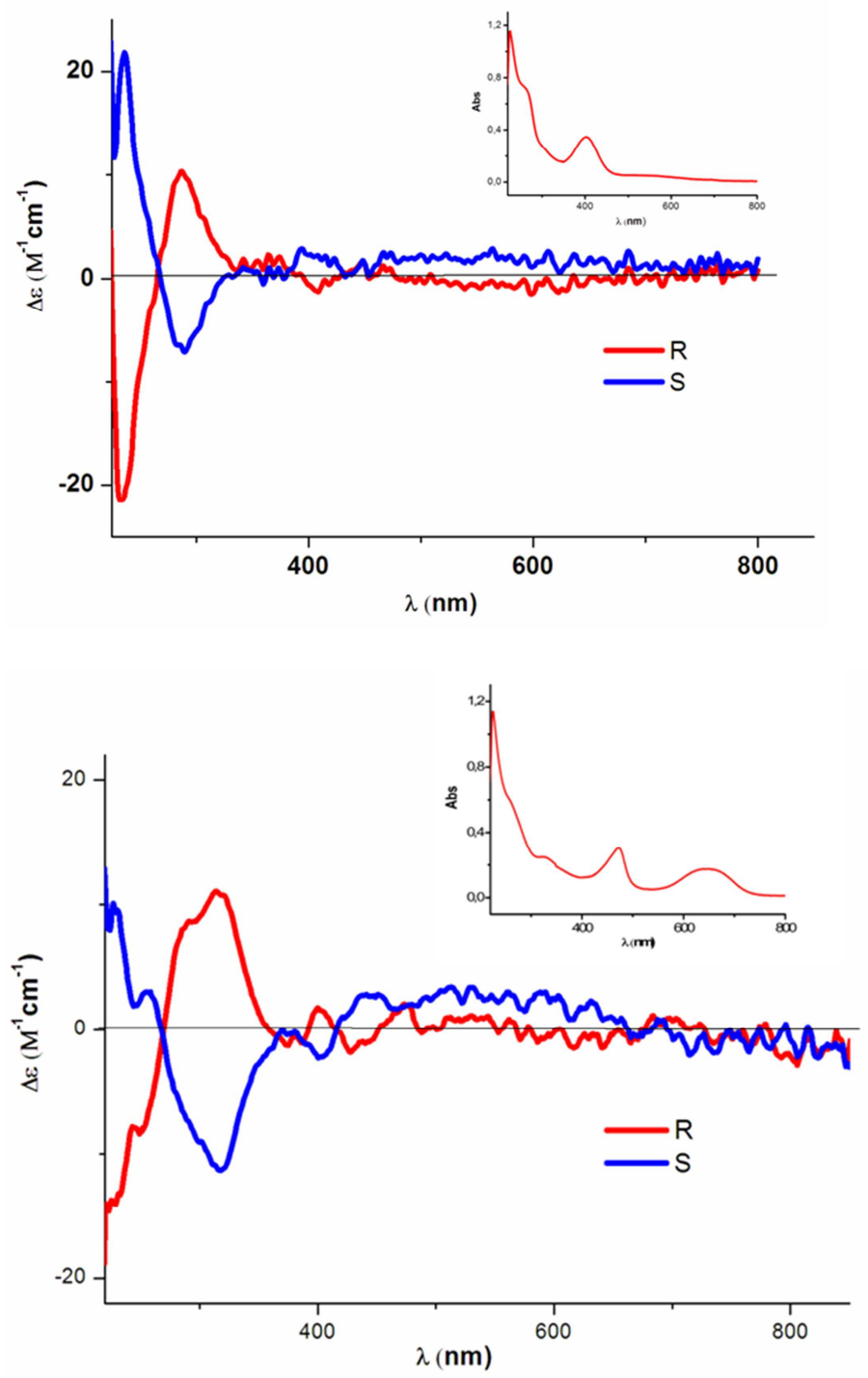

Fig. 7. $\mathrm{CD}$ spectra in $\mathrm{CH}_{2} \mathrm{Cl}_{2}$ (inserts: UV-vis absorption spectra) of neutral complex 2 (top) and monooxidized complex [2][TCNQ]. (bottom). 
The circular dichroism of the neutral dithiolene complexes $\mathbf{2}$ and the oxidized species $\mathbf{2}^{+\cdot}$ in [2][TCNQ] were investigated, in the UV-vis range. Circular dichroism (CD) spectra of complexes $(R)$ - and $(S)$-2 were recorded in $\mathrm{CH}_{2} \mathrm{Cl}_{2}$ at room temperature in the UV-Visible range and are reported in Figure 7. These CD spectra of both enantiomers exhibit a mirrorimage relationship. The CD spectrum of $(R)-\mathbf{2}$ for example exhibits a strong negative band at around $220 \mathrm{~nm}\left(\Delta \mathrm{E} \sim 20 \mathrm{M}^{-1} \mathrm{~cm}^{-1}\right)$ and a positive band at around $300 \mathrm{~nm}\left(\Delta \mathrm{E} \sim 10 \mathrm{M}^{-1} \mathrm{~cm}^{-1}\right)$ and a weak CD active band at $375 \mathrm{~nm}$. The CD spectra of the cation radical species $(R)-\mathbf{2}^{+}$. and $(S)-2^{+\cdot}$ in $[(R)-2][$ TCNQ] and $[(S)-2][$ TCNQ] show some similarities with those of the neutral species. Indeed in the oxidized species the $\mathrm{CD}$ active bands undergo a decrease of their intensity and a slight bathochromic shift.

In conclusion, we reported here the synthesis of novel chiral $\mathrm{Cp}_{2} \mathrm{Mo}$ (dithiolene) complexes by the use of chiral dithiolene ligands. Electrochemical investigations show that the introduction of the bulky phenyl ethyl group, which provides the chiral character to the ligand, does not modify the donating ability of these complexes compared with those substituted by smaller substituents such as ethyl or hydroxyethyl groups. Stoichiometric charge transfer salts for both isomers with TCNQ have been structurally characterized. The presence of this bulky phenyl ethyl group on the ligand induces steric hindrance which impedes any dimers organization for these oxidized donors in these chiral structures.

\section{Experimental section}

\section{Materials and methods}

All air-sensitive reactions were carried out under argon atmosphere. Melting points were measured on a Kofler hot-stage apparatus and are uncorrected. ${ }^{1} \mathrm{H}$ NMR and ${ }^{13} \mathrm{C}$ NMR spectra were recorded on a Bruker AV300III spectrometer using $\left(\mathrm{CD}_{3}\right)_{2} \mathrm{SO}$ as solvent. Chemical 
shifts are quoted in parts per million (ppm) referenced to tetramethylsilane. The circular dichroism (CD) spectra were recorded with a Jasco spectropolarimeter J-815 Mass spectra were recorded by the Centre Régional de Mesures Physiques de l'Ouest, Rennes. Elemental analysis were performed at the Centre Régional de Mesures Physiques de l'Ouest, Rennes. Tetrahydrofuran was distilled from sodium-benzophenone. Column chromatography was performed using silica gel Merck 60 (70-260 mesh). Cyclic voltammetry were carried out on a $10^{-3} \mathrm{M}$ solution of the complex in $\mathrm{CH}_{2} \mathrm{Cl}_{2}$, containing $0.1 \mathrm{M} \mathrm{nBu}_{4} \mathrm{NPF}_{6}$ as supporting electrolyte. Voltammograms were recorded at $0.1 \mathrm{Vs}^{-1}$ on a platinum disk electrode $(\mathrm{A}=$ $1 \mathrm{~mm}^{2}$ ). The potentials were measured versus Saturated Calomel Electrode. EPR spectra were recorded with an X-band Bruker ELEXYS 500 spectrometer from room temperature down to 4.2K. The Q-band spectra were recorded at room temperature. Integral intensity of a given signal was obtained by numerical double integration. Simulations were performed with Bruker WinEPR Simphonia.

Synthesis of $C p_{2} M o(1-p h e n y l e t h y l-t h i a z d t)(R)-,(S)$ - and $(R, S)-2$.

To a dry two necked flask containing thiazoline-2-thione 1 (150 mg, $0.397 \mathrm{mmol})$ in $12 \mathrm{~mL}$ of DMF was added $\mathrm{Cs}_{2} \mathrm{CO}_{3}(323 \mathrm{mg}, 0.99 \mathrm{mmol})$. The solution was stirred 30 minutes and $\mathrm{Cp}_{2} \mathrm{MoCl}_{2}(118 \mathrm{mg}, 0.397 \mathrm{mmol})$ was added. The reaction mixture was heated 2 hours at $80^{\circ} \mathrm{C}$. The solvent was removed in vacuo and $15 \mathrm{~mL}$ of water were added. The precipitate was filtered off, washed with water and $\mathrm{EtOH}$ to afford brown powder. Crystals were obtained by slow evaporation of an acetone solution for (R/S)-2 and (R)-2 and a THF solution for (S)-2.

(R)-2 : Yield $20 \%, \mathrm{Mp}>250^{\circ} \mathrm{C} .{ }^{1} \mathrm{H}$ NMR $(300 \mathrm{MHz}) \delta 1.92\left(\mathrm{~d}, 3 \mathrm{H}, \mathrm{CH}_{3}, \mathrm{~J}=7.2 \mathrm{~Hz}\right), 5.20$ (broad s, 5H, Cp), 5.46 (s, 5H, Cp), 6.72 ( broad signal, 1H, CH), 7.30 (m, 5H, Ar). ${ }^{13} \mathrm{C} \mathrm{NMR}$ $(75 \mathrm{MHz}) \delta 16.1\left(\mathrm{CH}_{3}\right), 56.0(\mathrm{CH}), 98.7(\mathrm{Cp}), 120.3(\mathrm{C}=\mathrm{C}), 126.4(\mathrm{Ar}), 126.6(\mathrm{Ar}), 127.8$ (Ar), 139.4 (Ar), $147.1(\mathrm{C}=\mathrm{C}), 185.9(\mathrm{C}=\mathrm{S})$. Anal. calcd for $\mathrm{C}_{21} \mathrm{H}_{19} \mathrm{NMoS}_{4} \cdot 0.5 \mathrm{H}_{2} \mathrm{O}: \mathrm{C}$, 
48.64; H 3.89; N, 2.70. Found: C, 48.65; H, 3.80; N, 2.85. HRMS (ESI) calcd for $\mathrm{C}_{21} \mathrm{H}_{19} \mathrm{NMoS}_{4} \mathrm{M}^{+}:$510.94544. Found: 510.9447.

(S)-2 : Yield $79 \%, \mathrm{Mp}>250{ }^{\circ} \mathrm{C} .{ }^{1} \mathrm{H}$ NMR $(300 \mathrm{MHz}) \delta 1.94\left(\mathrm{~d}, 3 \mathrm{H}, \mathrm{CH}_{3}, \mathrm{~J}=7.2 \mathrm{~Hz}\right), 5.20$ (broad s, 5H, Cp), 5.47 (s, 5H, Cp), 6.71 ( broad signal, 1H, CH), 7.34 (m, 5H, Ar). ${ }^{13} \mathrm{C}$ NMR $\left(75 \mathrm{MHz},\left(\mathrm{CD}_{3}\right)_{2} \mathrm{SO}\right) \delta 16.6\left(\mathrm{CH}_{3}\right), 56.8(\mathrm{CH}), 98.8(\mathrm{Cp}), 118.9(\mathrm{C}=\mathrm{C}), 126.3(\mathrm{Ar}), 126.6$ (Ar), 127.8 (Ar), 139.4 (Ar), $149.7(\mathrm{C}=\mathrm{C}), 186.0(\mathrm{C}=\mathrm{S})$. Anal. calcd for $\mathrm{C}_{21} \mathrm{H}_{19} \mathrm{NMoS}_{4}$ : C, 49.50; H 3.76; N, 2.75. Found: C, 49.08; H, 3.98; N, 2.86. HRMS (ESI) calcd for $\mathrm{C}_{21} \mathrm{H}_{19} \mathrm{NMoS}_{4} \mathrm{M}^{+}:$510.94544. Found: 510.9449.

(R,S)-2 : Yield $41 \%, \mathrm{Mp}>250^{\circ} \mathrm{C} .{ }^{1} \mathrm{H}$ NMR $(300 \mathrm{MHz}) \delta 1.94\left(\mathrm{~d}, 3 \mathrm{H}, \mathrm{CH}_{3}, \mathrm{~J}=7.2 \mathrm{~Hz}\right), 5.21$ (broad s, 5H, Cp), 5.47 (s, 5H, Cp), 6.72 (broad signal, 1H, CH), 7.34 (m, 5H, Ar). ${ }^{13} \mathrm{C}$ NMR $(75 \mathrm{MHz}) \delta 16.1\left(\mathrm{CH}_{3}\right), 55.9(\mathrm{CH}), 98.7(\mathrm{Cp}), 119.8(\mathrm{C}=\mathrm{C}), 126.3(\mathrm{Ar}), 126.7(\mathrm{Ar}), 127.8$ (Ar), 139.4 (Ar), $147.2(\mathrm{C}=\mathrm{C}), 185.9(\mathrm{C}=\mathrm{S})$. Anal. calcd for $\mathrm{C}_{21} \mathrm{H}_{19} \mathrm{NMoS}_{4} \cdot 0.5 \mathrm{H}_{2} \mathrm{O}: \mathrm{C}$, 48.64; H 3.89; N, 2.70; S, 24.73. Found: C, 48.55; H 4.04; N, 2.64; S, 24.32. HRMS (ESI) calcd for $\mathrm{C}_{21} \mathrm{H}_{19} \mathrm{NMoS}_{4} \mathrm{M}^{+}$: 510.94544. Found: 510.9455 .

Preparation of $\mathrm{Cp}_{2} \mathrm{Mo}$ (1-phenylethyl-thiazdt)-TCNQ.

To a hot solution of complex $2(10 \mathrm{mg}, 0.020 \mathrm{mmol})$ in $5 \mathrm{ml}$ of $\mathrm{CH}_{2} \mathrm{Cl}_{2}$ and $5 \mathrm{~mL}$ of $\mathrm{MeCN}$ was added a hot solution of TCNQ $\left(4.0 \mathrm{mg}, 0.020 \mathrm{mmol}\right.$ in $5 \mathrm{ml}$ of $\mathrm{CH}_{2} \mathrm{Cl}_{2}$ and $5 \mathrm{~mL}$ of $\mathrm{MeCN}$. The reaction mixture was refluxed 10 minutes and the solvent was slowly evaporated to afford dark crystals of sufficient quality for X-ray diffraction.

\section{X-Ray Crystallography.}

Data were collected on an APEX II Brucker AXS diffractometer with graphitemonochromated Mo-K $\alpha$ radiation $(\lambda=0.71073 \AA)$. The structure were solved by direct methods using the SIR97 program, ${ }^{17}$ and then refined with full-matrix least-square methods based on $F^{2}\left(\right.$ SHELXL-97) ${ }^{18}$ with the aid of the WINGX program. ${ }^{19}$ All non-hydrogen atoms 
were refined with anisotropic atomic displacement parameters. $\mathrm{H}$ atoms were finally included in their calculated positions. Details of the final refinements are given in Tables 5 for all compounds.

\section{Table 5}

Crystallographic data for the neutral complexes $(R)-\mathbf{2},(S)-\mathbf{2}$ and $(R, S)-\mathbf{2}$ and for the TCNQ salts TCNQ/(R)-2 and TCNQ/(S)-2

\begin{tabular}{|c|c|c|c|c|c|}
\hline Compound & $(R, S)-\mathbf{2}$ & $(S)-2$ & $(R)-2$ & {$[(R)-2][\mathrm{TCNQ}]$} & {$[(S)-2][$ TCNQ] } \\
\hline Formula & $\mathrm{C}_{21} \mathrm{H}_{19} \mathrm{MoNS}_{4}$ & $\mathrm{C}_{21} \mathrm{H}_{19} \mathrm{MoNS}_{4}$ & $\mathrm{C}_{21} \mathrm{H}_{19} \mathrm{MoNS}_{4}$ & $\mathrm{C}_{21} \mathrm{H}_{19} \mathrm{MoNS}_{4} \mathrm{C}_{12} \mathrm{H}_{4} \mathrm{~N}_{4}$ & $\mathrm{C}_{21} \mathrm{H}_{19} \mathrm{MoNS}_{4} \mathrm{C}_{12} \mathrm{H}_{4} \mathrm{~N}_{4}$ \\
\hline $\mathrm{FW}\left(\mathrm{g} \cdot \mathrm{mol}^{-1}\right)$ & 509.55 & 509.55 & 509.55 & 713.74 & 713.74 \\
\hline Crystal system & triclinic & monoclinic & monoclinic & orthorhombic & orthorhombic \\
\hline Space group & $P 1$ & $P 2_{1}$ & $P 2_{1}$ & $P 22_{1} 2_{1}$ & $P 22_{1} 2_{1}$ \\
\hline$a(\AA)$ & $10.7415(8)$ & $10.0839(5)$ & $10.0790(3)$ & $7.5923(4)$ & $7.5875(3)$ \\
\hline$b(\AA)$ & $11.1981(12)$ & $11.2875(7)$ & $11.2790(3)$ & $14.9150(7)$ & $14.9182(5)$ \\
\hline$c(\AA)$ & $17.1219(13)$ & $10.3061(4)$ & $10.2986(3)$ & $27.2511(12)$ & $27.3025(12)$ \\
\hline$\alpha\left(^{\circ}\right)$ & $94.560(3)$ & 90 & 90 & 90 & 90 \\
\hline$\beta\left(^{\circ}\right)$ & $91.154(3)$ & $116.507(2)$ & $116.465(1)$ & 90 & 90 \\
\hline$\gamma\left({ }^{\circ}\right)$ & $92.308(3)$ & 90 & 90 & 90 & 90 \\
\hline$V\left(\AA^{3}\right)$ & $2050.7(3)$ & $1049.75(9)$ & $1048.07(5)$ & $3085.9(3)$ & $3090.4(2)$ \\
\hline$T(\mathrm{~K})$ & $150(2)$ & $150(2)$ & $150(2)$ & $100(2)$ & $150(2)$ \\
\hline$Z$ & 4 & 2 & 2 & 4 & 4 \\
\hline$D_{\text {calc }}\left(\mathrm{g} \cdot \mathrm{cm}^{-3}\right)$ & 1.65 & 1.612 & 1.615 & 1.536 & 1.534 \\
\hline$\mu\left(\mathrm{mm}^{-1}\right)$ & 1.053 & 1.029 & 1.031 & 0.728 & 0.727 \\
\hline Total refls. & 26704 & 7987 & 9465 & 40758 & 14793 \\
\hline Uniq. refls. $\left(R_{\text {int }}\right)$ & $15557(0.0409)$ & $3561(0.0394)$ & $4712(0.0236)$ & $7032(0.0686)$ & 6983(0.0409) \\
\hline Unique refls. $(\mathrm{I}>2 \sigma(\mathrm{I}))$ & 11970 & 3251 & 4475 & 6593 & 5713 \\
\hline$R_{1}, w R_{2}$ & $0.0509,0.0965$ & $0.0458,0.1047$ & $0.0235,0.0532$ & $0.0316,0.0778$ & $0.0464,0.1015$ \\
\hline$R_{1}, w R_{2}$ (all data) & $0.0742,0.1091$ & $0.0524,0.1087$ & $0.0259,0.0548$ & $0.0354,0.080$ & $0.0613,0.10994$ \\
\hline GoF & 1.027 & 1.037 & 0.989 & 1.003 & 1.015 \\
\hline Flack parameter & $0.01(3)$ & $-0.07(7)$ & $-0.05(3)$ & $-0.02(3)$ & $-0.12(4)$ \\
\hline
\end{tabular}




\section{Acknowledgements :}

CD spectra were acquired on the Spectroscopy facility from BioSit (Universtié de Rennes 1).

\section{Appendix A. Supplementary Data}

CCDC 1408045-1408049 contain the supplementary crystallographic data for complexes $(R)-$, $(S)-,(R, S)-2,[(R)-2][\mathrm{TCNQ}]$ and [(S)-2][TCNQ] and CCDC 1409759 for [(R)-2][TCNQ] recorded at 100K. These data can be obtained free of charge via http://www.ccdc.cam.ac.uk/conts/retrieving.html, or from the Cambridge Crystallographic Data Centre,12 Union Road, Cambridge CB2 1EZ, UK; fax: (p44)1223-336-033; or e-mail: deposit@ccdc.cam.ac.uk.

\section{References}

${ }^{1}$ J. McMaster, J. M. Turner, C.D. Garner, Prog. Inorg. Chem. 52 (2004) 539-583.

${ }^{2}$ M. Fourmigué, Acc Chem. Res. 37 (2004)179-186.

${ }^{3}$ J. W.Lauher, R. Hoffmann, J. Am. Chem. Soc. 98 (1976) 1729-1742.

${ }^{4}$ N. J.Wiebelhaus, M. A. Cranswick, E. L. Klein, L. T. Lockett, D. L. Lichtenberger, J. H. Enemark, Inorg. Chem. 50 (2011) 11021-11031.

${ }^{5}$ M. Fourmigué, Coord. Chem. Rev. 178-180 (1998) 823-864.

${ }^{6}$ (a) R. Swietlik, D. Jankowski, M. Fourmigué, K. Yakushi, Vib. Spectrosc. 55 (2011) 195 200. (b) R. Swietlik, A. Lapinski, M. Fourmigué, K. Yakushi, J. Raman Spectrosc. 40 (2009) 2092-2098. (c) R. Clérac, M. Fourmigué, C. Coulon, J. Solid. State Chem. 159 (2001) 413-419. (d) B. Domercq, C. Coulon, M. Fourmigué, Inorg. Chem. 40 (2001) 371378. (e) R. Clerac, M. Fourmigué, J. Gaultier, Y. Barrans, P. A. Albouy, C. Coulon, Eur. Phys. J. B 9 (1999) 431-443. (f) R. Clérac, M. Fourmigué, J. Gaultier, Y. Barrans, P. A. 
Albouy, C. Coulon, Eur. Phys. J. B 9 (1999) 445-459. (g) M. Fourmigué, B. Domercq, I. V. Jourdain, P. Molinié, F. Guyon, J. Amaudrut, Chem. Eur. J. 4 (1998) 1714-1723. (h) M. Fourmigué, C. Lenoir, C. Coulon, F. Guyon, J. Amaudrut, Inorg. Chem. 34 (1995) 49794985.

${ }^{7}$ N. Bellec, A. Vacher, F. Barrière, Z. Xu, T. Roisnel, D. Lorcy, Inorg. Chem. 54 (2015) 5013-5020.

${ }^{8}$ (a) S. Eid, M. Guerro, D. Lorcy, Tetrahedron Lett. 47 (2006) 8333-8336. (b) S. Eid, M. Fourmigué, T. Roisnel, D. Lorcy, Inorg Chem. 46 (2007) 10647-10654. (c) A. FilatreFurcate, N. Bellec, O. Jeannin, P. Auban-Senzier, M. Fourmigué, A. Vacher, D. Lorcy, Inorg. Chem. 53 (2014), 8681-8690.

${ }^{9}$ (a) N. Tenn, N. Bellec, O. Jeannin, L. Piekara-Sady, P. Auban-Senzier, J. Íñiguez, E. Canadell, D. Lorcy J. Am. Chem. Soc., 131 (2009) 16961-16967. (b) G. Yzambart, N. Bellec, N. Ghassan, O. Jeannin, T. Roisnel, M. Fourmigué, P. Auban-Senzier, J. Íñiguez, E. Canadell, D. Lorcy, J. Am. Chem. Soc., 134 (2012) 17138-17148. (c) Y. Le Gal, T. Roisnel, P. Auban-Senzier, T. Guizouarn, D. Lorcy, Inorg. Chem. 53 (2014) 8755-8761.

${ }^{10}$ S. Eid, T. Roisnel, D. Lorcy, J. Organomet. Chem. 693 (2008) 2755-2760.

${ }^{11}$ T. Bsaibess, M. Guerro, Y. Le Gal, D. Sarraf, N. Bellec, M. Fourmigué, F. Barrière, V. Dorcet, T. Guizouarn, T. Roisnel, D. Lorcy, Inorg. Chem. 52 (2013) 2162-2173.

${ }^{12}$ Y. Le Gal, A. Vacher, V. Dorcet, M. Fourmigué, J. Crassous, D. Lorcy, New. J. Chem. 39 (2015) 122-129.

${ }^{13}$ (a) C. Roussel, A. Liden, M. Chanon, J. Metzger, J. Sandström, J. Am. Chem. Soc., 98 (1976), 2847-2852. (b) J. Roschester, U. Berg, M. Pierrot, J. Sandtröm, J. Am. Chem. Soc., 109 (1987) 492-507.

${ }^{14}$ J. S. Chappell, A. N. Bloch, W. A. Bryden, M. Maxfield, T. O. Poehler, D.O. Cowan, J. Am. Chem. Soc. 103 (1981) 2442-2243. 
${ }^{15}$ M. L. H.Green, W. E. Lindsell, J. Chem. Soc. A (1967) 1455-1458.

${ }^{16}$ A. L. Whalley, A. J. Blake ,D. Collison, E. S. Davies, H. J. Disley, M. Helliwell, F. E. Mabbs, J. McMaster, C. Wilson, C.D. Garner, Dalton Trans. 40 (2011) 10457-10472.

${ }^{17}$ A. Altomare, M. C. Burla, M. Camalli, G. Cascarano, C. Giacovazzo, A. Guagliardi, A. G. G. Moliterni, G. Polidori, R. Spagna, J. Appl. Cryst. 32 (1999) 115-119.

${ }^{18}$ G. M. Sheldrick, Acta Cryst. A64 (2008) 112-122.

${ }^{19}$ L. J. Farrugia, J. Appl. Cryst. 45 (2012) 849-854. 


\section{Graphical Abstract Synopsis}

The synthetic approach towards chiral $\mathrm{Cp}_{2} \mathrm{Mo}\left(\mathrm{R}^{*}\right.$-thiazdt $)$ complexes, $\left(\mathrm{R}^{*}=1\right.$-phenylethyl $)$, and their ability to form charge transfer salts with TCNQ are presented.

\section{Graphical Abstract Pictogram}
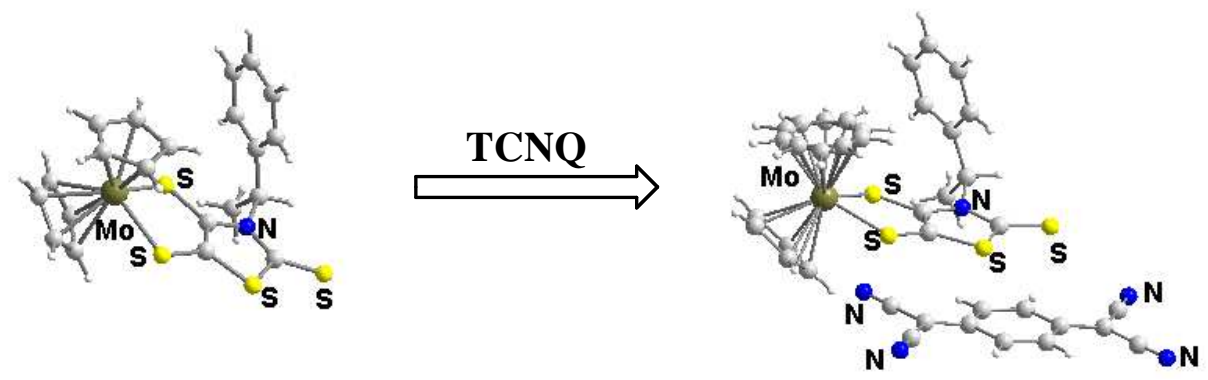